\title{
INTRODUCTION TO THE SPECIAL SECTION ON INTEGRATING ACCESSIBILITY INTO ONLINE LEARNING
}

Kristen Betts, Ed.D.

Forbes Education

Mark Riccobono, M.S.Ed.

Jernigan Institute, National Federation of the Blind

Bill Welsh, M.A.

Rutgers, The State University of New Jersey

\section{KEY WORDS}

Accessibility, technology, disabilities, equal access, equal opportunity, procurement, online learning, online education, higher education, barriers, student success

\section{DEDICATION}

This special section of the Journal of Asynchronous Learning Networks, Integrating Accessibility into Online Learning, is dedicated to Dr. Bruce N. Chaloux. Bruce served as the CEO and executive director of the Sloan Consortium since March 2012. He was a visionary leader in online learning and committed to accessibility and student success. Visit the Sloan-C website for information about Bruce Chaloux and his legacy work with the Sloan Consortium: http://sloanconsortium.org/Bruce_Chaloux_Memorial.

\section{INTRODUCTION}

This special section of the Journal of Asynchronous Learning Networks, Integrating Accessibility into Online Learning, is a compilation of papers, interviews, and webinars that provide an overview of the broad spectrum of issues related to accessibility, online learning, and student success. The proliferation of technology and online learning have transformed higher education in terms of national enrollments and instructional delivery. Data reveals that between fall 2002 and fall 2012, the number of higher education students taking at least one online course increased from 1.6 million to 6.7 million, representing a growth rate of $21 \%$ [1]. While online learning provides extensive new opportunities for students to enroll in degree and certificate programs, these opportunities are closely linked to accessibility. An institutional commitment to accessibility is needed to support success for all students. Universities must provide students with disabilities equal access to all programs, including activities and services that allow an equal opportunity for them to actively participate and to achieve the same results as other students. This special section showcases research, trends, and recommended best practices to increase accessibility and success in online learning for students with disabilities.

\section{DATA ON INDIVIDUALS WITH DISABILITIES}

The 23rd anniversary of the Americans with Disabilities Act (ADA) was celebrated in July 2013. This comprehensive mandate is significant since it opens gateways to "equality of opportunity, full participation, independent living, integration and economic self-sufficiency for all persons with disabilities" [2]. Individuals with disabilities are integral contributors to the economy and society. They represent a significant market of consumers, and they spur technological innovation and 
entrepreneurship [3]. They also bring unique skill sets to the workforce, which when combined with the completion of a higher education certificate or degree, will be critical to meeting employment projections for 2020. According to the Center on Education and the Workforce, there will be 55 million job openings in the United States through 2020, of which $35 \%$ of the openings will require at least a bachelor's degree, and 30\% will require some college or an associate's degree [4].

Before providing an overview of the papers, interviews, and webinars for this special JALN focus, it is important to share data on individuals with disabilities. The data below is derived from the World Health Organization, Disability Funders Network, U.S. Census Bureau, National Center for Education Statistics (NCES), and U.S. Department of Labor.

- More than 1 billion people in the world today have a disability [5].

- "People with disabilities constitute the nation's largest minority group, and the only group any of us can become a member of at any time" [6].

- "People with disabilities represent the single largest minority group seeking employment in today's marketplace" [6].

- "Of the 69.6 million families in the United States, more than 20 million have at least one family member with a disability" [6].

- There is $19 \%$ of the civilian non-institutional population in the United States that has a disability [7].

- An existing 11\% of undergraduates in both 2003-2004 and 2007-2008 graduation classes reported having a disability [8].

- The employment rate in August 2013 was $20.5 \%$ for people with disabilities and $69.1 \%$ for people without disabilities [9].

- The unemployment rate in August 2013 was $14.1 \%$ for people with disabilities and $7.1 \%$ for people without disabilities [9].

The Disability Status Report, released in 2012 by Cornell University, provides extensive data on individuals with disabilities in the United States [10]. Table 1 highlights comparative data from 2011 for working-age adults with and without a disability.

Table 1. Working-Age Adults Comparative Table

\begin{tabular}{|l|c|c|}
\hline & $\begin{array}{c}\text { Working-Age Adults } \\
\text { With a Disability }\end{array}$ & $\begin{array}{c}\text { Working-Age Adults } \\
\text { Without a Disability }\end{array}$ \\
\hline $\begin{array}{l}\text { Completed a Bachelor's Degree } \\
\text { or More }\end{array}$ & $12.5 \%$ & $31.2 \%$ \\
\hline Full-time Employment & $20.7 \%$ & $55.5 \%$ \\
\hline Household Income & $\$ 36,700$ & $\$ 60,400$ \\
\hline Poverty Rate & $12.4 \%$ & $27.8 \%$ \\
\hline
\end{tabular}

The Bureau of Labor Statistics published an economic new release in 2013 entitled, "Persons with a Disability: Labor Force Characteristics" [11]. The news release provides comparative data and findings related to employment for individuals with and without disabilities. Highlights from the news release are provided:

- For all age groups, the employment-population ratio was much lower for persons with a disability than for those with no disability.

- Workers with a disability were more likely than those with no disability to work part time.

- Those with a disability were less likely than those with no disability to work in management, professional, and related occupations professional, and related occupations.

- Persons with a disability with higher levels of education were more likely to be employed than those with less education [11]. 


\section{ACCESSIBILITY COLLECTION}

The accessibility collection of papers represents diverse areas of accessibility and online learning. The paper "Understanding Disabilities \& Online Student Success" provides a foundation for understanding disabilities and the types of support and services needed in online learning by students with disabilities. "Strategies to Increase Online Student Success for Students with Disabilities" provides an online learning perspective from students with different disabilities who graduated from online programs. This paper also includes links with video and audio introductions from the students and graduates. The paper, "K-12 Online Learning and Students with Disabilities: Perspectives from State Special Education Directors," presents data collected from 46 state and non-state jurisdiction special education directors about K-12 online learning. "Designing Online Courses for Screen Reader Users" presents the findings of a review conducted by a skilled screen reader user of multiple online courses at one institution to assess the extent to which the courses were navigable and understandable to online students using these assistive technologies. The paper, "Programmatic, Systematic, Automatic: An Online Course Accessibility Support Model," presents an online course accessibility support model that was developed and implemented by the University of Central Florida's Center for Distributed Learning.

\section{INTERVIEWS}

The interviews included in this $J A L N$ special issue provide a legal and national perspective on accessibility and online learning. Daniel F. Goldstein, a partner with the law firm of Brown, Goldstein \& Levy, provides critical insight on federal regulations and four steps for a campus to provide equal opportunity to all students. Mark Riccobono, the director of the Jernigan Institute, National Federation of the Blind, and Kelly Hermann, chair of the Association of Higher Education And Disability's Special Interest Group on Online and Distance Learning, discuss the opportunities and the challenges related to online learning for students with disabilities. They also provide recommendations regarding student support services and discuss the services that are available to higher education institutions by both of their organizations.

\section{SLOAN-C ACCESSIBILITY WEBINAR SERIES 2013: STUDENT \& FACULTY SUCCESS IN ONLINE EDUCATION}

The Sloan Consortium hosted an Accessibility Webinar Series in spring 2013 that included four 90minute webinars [11]. The webinars focused on different areas related to accessibility, including federal regulations, national resources, and effective practices for student and faculty success. Each webinar brought together a panel of administrative leaders, faculty, and students to discuss accessibility from professional as well as personal experiences. Approximately 200 to 700 sites registered to attend each of the four webinars. The titles and overviews for each of the four webinars are provided:

1. Administrative Panel: Understanding the Law \& Building Accessible Institutional Infrastructures

This panel included four accessibility specialists from the National Federation of the Blind, Pennsylvania State University, California Community Colleges, and EASI (Equal Access to Software and Information). The panel identified critical issues that all higher education institutions should be addressing and shared effective practices and available resources for creating accessible institutional infrastructures that support student and faculty success in online education.

2. Student \& Alumni Panel: What Students with Disabilities Want Faculty \& Administrators to Know

This panel included current online students and online alumni with different disabilities. Each person provided a personal introduction and then shared what faculty and administrators need to 
know from their perspectives about accessibility, working with students with disabilities, and strategies to increase online student success.

\section{Faculty Panel: What Faculty with Disabilities Want Institutions to Know}

This panel included four faculty with expertise in accessibility. Each faculty member provided a self-introduction and discussed the position held within higher education. The panel then shared recommendations and resources for supporting faculty (full-time, part-time, and adjunct) success in online education.

\section{Accessibility Specialists: Understanding "Invisible" Disabilities \& What this Means for Online Education}

This panel included four accessibility specialists from Empire State University, Pennsylvania State University, Drexel University, and WebAIM. Each panel member provided a selfintroduction and discussed work with "invisible" disabilities. The panel then shared effective practices and available resources to support students and faculty with invisible disabilities in online education.

The Sloan-C website (http://sloanconsortium.org/institute/webinars/2013/accessibility-series) has links to each of the four open-access webinars, including the recorded sessions with captioning and the presentation slides with transcripts [12].

\section{CONCLUSION}

The papers, interviews, and webinars included in this $J A L N$ special section provide a broad overview of the extensive topics that relate to accessibility and online learning. All students have a right to be educated, to participate fully in an on-campus and online course, and to equally access all technologies utilized in the course. Technology is not inherently inaccessible - it has to be deliberately designed that way - and when technology is built with accessibility in mind, it expands the circle of participation and enhances our educational environments.

Many individuals with disabilities enroll in online learning because it may provide easier access for them due to their disabilities. Online learning may not require transportation, expensive residential housing, or other potential barriers that individuals with disabilities face with resident instruction educational programs. Online education programs have the opportunity to demonstrate how effective planning and implementation of accessibility in technology transforms opportunities for students with disabilities. Institutions of higher education that are proactive in the realm of providing equal access will not only increase revenues, but will also provide better opportunities for individuals with disabilities who will be in better positions to obtain gainful employment. As Daniel F. Goldstein shares in his interview in this $J A L N$ special section, "The first step is to stop the proliferation of inaccessible technology by adopting procurement policies that require that the university license only accessible technology. As more schools do so, vendors will begin to compete on the basis of accessibility and this will become an easier task for universities." This journal volume is meant to illuminate this leadership opportunity, frame the new paradigm, and point to some effective practices.

This special section of $J A L N$ is also intended to create a more open dialogue about effective means for improving accessibility in online education programs. We have not realized the fully accessible online education environment in all programs. Rather than ignoring areas in need of improvement, this volume is meant to open new avenues for discussion and planning for improvement. The materials included may raise questions that the editors had not anticipated. Therefore, what follows should not be considered a handbook to answer all the questions but rather a guidebook to begin building a community of committed leaders who want to work vigorously towards the achievement of equal access in online learning. While programs have a legal obligation that needs to be met, there is a more important leadership opportunity available to build outstanding education that is available to all. 


\section{ACKNOWLEDGEMENTS}

We would like to thank the authors who contributed papers to the Integrating Accessibility in Online Learning special section of the Journal of Asynchronous Learning Networks. We would also like to thank the Association of Higher Education And Disabilities; the law firm of Brown, Goldstein \& Levy; and the National Federation of the Blind for their contributions and their advocacy and ongoing commitment to accessibility. We would like to recognize Zeren Eder for her work with the Sloan-C Accessibility Webinar Series. In closing, we would like to recognize and thank Gary Miller (interim $J A L N$ editor) and Janet Moore (former JALN editor) for their support of this special edition of JALN. We'd also like to thank Sloan Consortium for their commitment to accessibility, online learning, and student success.

\section{REFERENCES}

1. Allen, I.E., and Seaman, J. Changing Course: Ten Years of Tracking Online Education in the United States (2012). http://sloanconsortium.org/publications/survey/changing_course_2012.

2. U.S. Department of Justice. Celebrating Enforcement of the ADA: An Anniversary Week Blog. 23 Years of the ADA (2013). http://www.ada.gov/ada-23-anni.htm.

3. Brault, M.W. Americans With Disabilities: 2010. Current Population Reports, Household (July 2012). http://www.census.gov/prod/2012pubs/p70-131.pdf.

4. Georgetown University. Recovery: Job Growth and Education Requirements Through 2020. (June 2013). http://cew.georgetown.edu/recovery2020/.

5. World Health Organization. World Report on Disability. World Bank: Malta. (2011). http://www.who.int/disabilities/world report/2011/en/index.html.

6. Disability Funders Network. Disability Stats and Statistics. http://www.disabilityfunders.org/disability-stats-and-facts.

7. U.S. Census. Profile America Facts for Features: 20th Anniversary of Americans with Disabilities Act. Washington, DC. (May 2010). http://www.census.gov/newsroom/releases/archives/facts_for_features_special_editions/cb10ff13.html.

8. NCES Students with Disabilities U.S. Department of Education. National Center for Education Statistics. Digest of Education Statistics, 2011. (2012). http://nces.ed.gov/fastfacts/display.asp?id=60.

9. U.S. Department of Labor. Labor Force Participation (August 2013). http://www.dol.gov/odep/.

10. Erickson, W., Lee, C., and von Schrader, S. Disability Status Report: United States. Ithaca, NY: Cornell University Employment and Disability Institute (EDI). (2012). http://www.disabilitystatistics.org/StatusReports/2011-PDF/2011StatusReport US.pdf?CFID=2103415\&CFTOKEN=2d3ebe3d17977656-9E6CB1A3-5056-B4000DBE6652588D6993\&jsessionid=8430b84e3f194c982d7d3a707b7f1eb7a7b3.

11. Bureau of Labor Statistics. Persons with a Disability: Labor Force Characteristics News Release (June 12, 2013). http://www.bls.gov/news.release/disabl.htm.

12. Sloan-C Accessibility Webinar Series 2013. http://sloanconsortium.org/institute/webinars/accessibility-series. 